\title{
STYMULOWANIE PRYWATNYCH OSZCZĘDNOŚCI EMERYTALNYCH NA PRZYKŁADZIE KANADY i NOWEJ ZELANDII
}

Teresa H. Bednarczyk dr hab. prof. nadzw., Zakład Ubezpieczeń, Wydział Ekonomiczny, UMCS

\section{Wprowadzenie}

Dokonujące się przemiany demograficzne, społeczne oraz gospodarcze w Europie i na świecie stanowią duże wyzwanie dla stabilności publicznych systemów emerytalnych opartych na zasadzie pay-as-you-go. W związku z tym zachodzi pilna potrzeba rozbudowy kapitałowych programów emerytalnych, opartych na indywidualnej zapobiegliwości, tak aby nabrały one cech powszechności i uzupełniały skutecznie lukę w stopach zastąpienia z filarów publicznych. Wówczas system emerytalny ma szanse sprawnie wykorzystywać efekt synergii obu typów filarów, ograniczać ryzyko występujące $\mathrm{w}$ każdym $\mathrm{z}$ nich $\mathrm{z}$ osobna i jednocześnie ma szanse zapewnić stabilne finansowanie przyszłych świadczeń emerytalnych.

Polska gospodarka potrzebuje oszczędności emerytalnych, a jednocześnie przyszli emeryci potrzebują dodatkowego kapitału, aby uzupełnić w przyszłości prognozowany niższy poziom świadczeń emerytalnych z systemu publicznego. W Polsce funkcjonują już programy gromadzenia dodatkowych oszczędności emerytalnych, wspierane przez państwo. Jednak nie przynoszą one istotnego wzrostu nowych oszczędności. W 2015 r. wartość łącznych aktywów zgromadzonych zarówno w formie zbiorowego oszczędzania (PPE), jak i w indywidualnych planach emerytalnych (IKE i IKZE) wyniosła $16,92 \mathrm{mld}$ zł, co stanowiło zaledwie 0,94 proc. $\mathrm{PKB}^{1}$. Po kilkunastu latach funkcjonowania dobrowolnych programów emerytal-

1 W 2014 r. średnia ważona relacji aktywów zgromadzonych w prywatnych funduszach emerytalnych do PKB dla krajów OECD wyniosła 84,4 proc. [OECD 2015a: 9]. 
nych poziom społecznej partycypacji w nich, zwłaszcza osób o niskich dochodach, jest nadal bardzo niewielki ${ }^{2}$, czego nie można tłumaczyć jedynie w kategoriach czysto ekonomicznych. Problem leży po stronie bodźców systemowych, które oceniane są jako mało atrakcyjne dla szerszej populacji. Dlatego w trzecim filarze emerytalnym konieczne są zmiany i wprowadzenie nowych, znacznie skuteczniejszych zachęt do oszczędzania.

Kanadyjski system emerytalny jest jednym z najlepiej ocenianych pod względem stabilności finansowej, adekwatności świadczeń oraz integralności publicznego i prywatnego systemu emerytalnego. Powszechna emerytura państwowa zapewnia ochronę ludzi starszych przed ubóstwem, zaś relatywnie wysoki poziom dodatkowych oszczędności emerytalnych skutecznie uzupełnia niewysoką stopę zastąpienia z systemu publicznego, szczególnie w grupie osób średnio zamożnych i zamożnych. Nowa Zelandia z kolei jest przykładem kraju, który odniósł największy sukces $\mathrm{w}$ angażowaniu społeczeństwa $\mathrm{w}$ dobrowolne programy emerytalne i mobilizowanie dodatkowych oszczędności emerytalnych. Wprowadzony tam w lipcu 2007 roku nowatorski system dobrowolnych kont emerytalnych pod nazwą KiwiSaver z roku na rok odnotowuje wzrost uczestników i aktywów tam zgromadzonych. Dzięki temu Nowa Zelandia prezentuje jeden z najwyższych na świecie wskaźników partycypacji pracowników $\mathrm{w}$ dobrowolnych formach oszczędzania na emeryturę.

Głównym celem opracowania jest porównanie rozwiązań systemowych dotyczących stymulowania dodatkowych oszczędności emerytalnych w Kanadzie i w Nowej Zelandii. Opracowanie wymagało studiów literaturowych oraz analizy źródeł statystycznych, raportów i opracowań instytucji krajowych i zagranicznych.

\section{Oszczędności emerytalne i instrumenty ich wspierania}

Oszczędności podmiotów gospodarujących są wynikiem celowego procesu przesuwania konsumpcji bieżącej na rzecz konsumpcji przyszłej. Stanowią odłożoną w czasie konsumpcję w celu maksymalizowania funkcji użyteczności [Czechowska 2013: 59]. W teorii ekonomii ziden-

2 Wskaźnik partycypacji - odsetek uczestników dobrowolnych programów emerytalnych w relacji do ogółu pracujących w wieku 15-64 lat. Na koniec 2015 r. wskaźnik partycypacji w PPE wynosił - 2,41 proc. w IKE - 5,3 proc. oraz w IKZE 3,7 proc. [UKNF 2014]. 
tyfikowano wiele motywów (bodźców) skłaniających do oszczędzania. W świetle ekonomii klasycznej i neoklasycznej wielkość oszczędności jest pochodną stopy procentowej, która stanowi wynagrodzenie za rezygnację z konsumpcji bieżącej na rzecz wyższego poziomu konsumpcji w okresach późniejszych. W ujęciu ekonomii Keynesowskiej poziom oszczędności w okresie długim jest zdeterminowany przez skłonność do oszczędzania, która zależy przede wszystkim od wysokości łącznych dochodów [Keynes 2003: 142-143]. W świetle hipotezy cyklu życia F. Modiglianiego [Modigliani i Brumberg 1954: 388-436] oraz teorii dochodu permanentnego M. Friedmana [Friedman 1957] - podstawowym motywem oszczędzania jest chęć zapewnienia sobie odpowiedniego poziomu i standardu życia w okresie emerytalnym. Cel emerytalny pojawia się w większości współczesnych klasyfikacji motywów oszczędzania ${ }^{3}$.

Oszczędności emerytalne mogą być rozpatrywane w różnym ujęciu, zarówno węższym jak i szerszym. W niniejszym opracowaniu do oszczędności emerytalne będą zaliczane różne formy prywatnych planów emerytalnych, zakładowych i indywidualnych, dobrowolnych lub obowiązkowych (bądź quasi obowiązkowych), zarządzanych na zasadach rynkowych (kapitałowych). Jako oszczędności emerytalne będą traktowane jedynie te umowy inwestycyjne, które mają jasno zdefiniowany cel emerytalny. Tym samym jako oszczędności nie będą tutaj traktowane obligatoryjne składki odprowadzane do publicznych systemów emerytalnych, finansowanych na zasadzie repartycyjnej (pay-as-you-go), a także środki gromadzone w otwartych funduszach emerytalnych, które pochodzą z części obligatoryjnych składek odprowadzanych na ubezpieczenia publiczne.

Oszczędności emerytalne pełnią wiele funkcji. Mikroekonomiczna funkcja oszczędności emerytalnych polega na uzupełnieniu świadczeń emerytalnych pochodzących $\mathrm{z}$ systemu publicznego oraz zabezpieczaniu godnego poziomu życia po zakończeniu aktywności zawodowej. Z makroekonomicznego punktu widzenia oszczędności emerytalne stanowią ważne źródło akumulacji kapitału finansowego, który przekształcony efektywnie w inwestycje rzeczowe pozytywnie wpływa na wzrost gospodarczy. W związku z tym $\mathrm{w}$ interesie rządów jest wspieranie procesu dodatkowego oszczędzania na okres starości, za pomocą ulg podatkowych lub innych narzędzi finansowych.

3 Jednak motywy nie zawsze pokrywają się z celami, na jakie gromadzone są oszczędności. Często gospodarstwa domowe oszczędzają bez z góry określonego celu. Szerzej na temat motywów oszczędzania zob. m.in.: Swacha-Lech [2013: 430-432]. 
W praktyce spotkać można różne rozwiązania dotyczące stosowanych ulg podatkowych związanych $\mathrm{z}$ oszczędzaniem w zinstytucjonalizowanych planach emerytalnych. Najczęściej występuje zwolnienie podatkowe, które może być stosowane w odniesieniu do trzech elementów: periodycznych wpłat wnoszonych do programów emerytalnych, zysków inwestycyjnych oraz świadczeń wypłacanych z programów emerytalnych. W literaturze wyodrębniono następujące modele opodatkowania: EET (exempt-exempt-tax), TEE (tax-exempt-exempt), TTE (tax-tax-exempt), ETT (exempt-tax-tax) oraz EEE (exempt-exempt-exempt). W krajach wysoko rozwiniętych najbardziej popularny jest system EET, czyli odpisywanie wpłaconych składek oszczędnościowych od podstawy opodatkowania, zwolnienia z podatku zysków wypracowanych przez kapitał emerytalny w okresie inwestowania oraz opodatkowanie wypłacanych świadczeń emerytalnych [Pieńkowska-Kamieniecka i Ostrowska-Dankiewicz 2013: 120].

Jak pokazują niektóre badania naukowe, ulgi podatkowe nie zawsze przyczyniają się do istotnego wzrostu oszczędności emerytalnych i nie zawsze zapewniają wysoki poziom partycypacji, zwłaszcza wśród osób o niskich i średnich dochodach. System zachęt w systemie opodatkowania EET powoduje, że zyskują przede wszystkim osoby osiągające wysokie dochody. Z kolei osoby gorzej zarabiające, które płacą niskie podatki, w mniejszym stopniu odczuwają korzyści z tytułu ulg podatkowych i tym samym mają mniejsze bodźce do oszczędzania w zinstytucjonalizowanych planach emerytalnych. W efekcie zachęty w systemie opodatkowania EET powodują transfer fiskalny od ogółu podatników do osób o najwyższych dochodach [Kawalec i in. 2015: 21].

Innym sposobem wspierania procesu mobilizowania oszczędności emerytalnych są dopłaty do składek uczestników programów oszczędnościowych (matching contributions), realizowane przez rządy i/lub pracodawców. Mechanizm dopłat do składek oszczędnościowych jest rozwiązaniem, które występuje samodzielnie lub w połączeniu $\mathrm{z}$ zasadą automatycznego zapisu (automatic-enrolment). Zasada automatycznego zapisu znajduje wsparcie $\mathrm{w}$ dorobku ekonomii behawioralnej, w świetle której ludzie są generalnie niechętni do wprowadzania jakichkolwiek zmian. W przypadku gdy system oszczędzania emerytalnego jest dobrowolny część ludzi nie weźmie w nim udziału właśnie z niechęci do zmian, a nie dlatego, że uważa, że jest on im niepotrzebny. Automatyczny zapis pozwala na uniknięcie tego problemu [Samoń 2012: 14]. 


\section{Wspieranie dobrowolnych oszczędności emerytalnych w Kanadzie}

Kanada zaliczona jest do państw o charakterze liberalnym i prorynkowym. Wiodącą rolę w systemie emerytalnym pełnią rozwiązania podporządkowane rynkowi. Państwo dąży do minimalizacji wydatków na cele emerytalne, gwarantując jedynie niezbędne minimum w ramach emerytury obywatelskiej [Esping-Andersen 2010]. W rezultacie wydatki publiczne na cele emerytalne są prawie o połowę niższe niż średnia dla krajów OECD. Za to wydatki prywatne są prawie o połowę wyższe niż średnia dla krajów OECD [Actuarial Report...: 33].

Kanada należy do grona tych krajów, w których dochody z kapitału odgrywają bardzo ważną rolę w uzupełnianiu dochodów emerytalnych z systemu publicznego. W 2012 r. dochody z kapitału (funduszy emerytalnych i innych form inwestycji) stanowiły 39\% dochodów Kanadyjczykom w wieku 65 i więcej lat. Stawia to Kanadę na pierwszym miejscu wśród krajów OECD pod względem udziału kapitału prywatnego w strukturze dochodów osób starszych. Drugie miejsce pod tym względem zajmuje Nowa Zelandia [OECD 2015b: 169].

O istotnej roli rozwiązań rynkowych w kanadyjskim systemie emerytalnym świadczą też aktywa zgromadzone $\mathrm{w}$ funduszach emerytalnych. W 2014 r. ich wysokość w relacji do PKB stanowiła 76,2 proc. (przy średniej ważonej dla krajów OECD - 84,4 proc.). Większy udział funduszy emerytalnych w PKB odnotowano jedynie w takich krajach, jak: Holandia (159,3 proc.), Islandia (146,8 proc.), Szwajcaria (120,3 proc.), Australia (110 proc.), Wielka Brytania (96 proc.), USA ( 83 proc.), przy czym w Holandii, Islandii i Szwajcarii kapitałowe ubezpieczenia emerytalne są dla pracowników de facto obowiązkowe lub quasi-obowiązkowe [OECD 2015b: 9].

Gospodarcze tradycje anglosaskiego kręgu kulturowego, wywarły duży wpływ na kształtowanie się postaw kanadyjskiego społeczeństwa, które podobnie jak amerykańskie wykazuje duże przywiązanie do indywidualizmu i atomizacji społeczeństwa. Jest to istotne ze społecznego i ekonomicznego punktu widzenia, gdyż zaufanie społeczne sprzyja rozwojowi nowoczesnego rynku prywatnych instytucji finansowych. Jest to również ważne w kontekście systemu emerytalnego, zwłaszcza gdy znaczna część emerytur jest zapewniana poprzez fundusze emerytalne i inne instrumenty rynku finansowego. Kanadyjskie społeczeństwo odznacza się wysokim stopniem zaufania do instytucji finansowych. Wynika to $\mathrm{z}$ głęboko zakorzenionych moralnych i etycznych norm społecz- 
nych, które wymagają od partnerów uczciwości w interesach [Fukuyama 1997: 181].

Stabilność i funkcjonalność kanadyjskiego systemu emerytalnego wynika z jego zróżnicowania. System emerytalny składa się z trzech filarów, z których dwa pierwsze są obligatoryjne i administrowane przez państwo ${ }^{4}$. Podstawowy poziom świadczeń emerytalnych w ramach pierwszego filara zapewnia Program Zabezpieczania Osób Starszych (Old Age Security) wraz z programami wspierającymi - Guaranteed Income Supplement oraz programami zasiłków (Allowance) i zasiłków dla wdów i wdowców (Allowance for the Survivor). Stopa zastąpienia $\mathrm{z}$ tego filara jest dość niska, wynosi ok. 15\% [Old Age Security Benefits...].

Drugi filar emerytalny - Canada/Quebec Pension Plan oparty jest na modelu ubezpieczeniowym (pay-as-you-go). Do płacenia składek ubezpieczeniowych zobowiązany jest każdy dorosły obywatel w wieku od 18-70 lat, który uzyskuje dochód roczny w przedziale 3 500-54 900 CAN (przedział obowiązujący w 2016 r.), a także osoby prowadzące własną działalność gospodarczą. Emerytura z filara ubezpieczeniowego jest obliczana na zasadzie zdefiniowanego świadczenia, a nie zdefiniowanej składki. Stopa zstąpienia z filara ubezpieczeniowego wynosi ok. 25\%. System kanadyjski nie przewiduje minimalnej emerytury z systemu ubezpieczeniowego, natomiast przewiduje kwotę maksymalnego miesięcznego świadczenia emerytalnego dla osób w wieku 65 i więcej lat ${ }^{5}$.

Trzeci filar emerytalny w Kanadzie jest całkowicie dobrowolny i składa się z pracowniczych (zakładowych) programów emerytalnych (Registered Pension Plans), indywidualnych oszczędnościowych planów emerytalnych (Registered Retirement Savings) oraz wolnych od podatku kont oszczędnościowych (Tax-Free Saving Accounts). Są organizowane i sponsorowane przez pracodawców. Uśredniona składka na rzecz tych programów kształtuje się na poziomie 8,5 proc. wynagrodzenia brutto [Kłos 2012, s. 8]. Wszystkie zakładowe programy emerytalne, które są zarejestrowane w Kanadyjskiej Agencji Podatkowej (Canada Revenue Agency) dostarczają ulg podatkowych w systemie EET (Exempt, Exempt, Tax). Ulgi podatkowe obejmują zarówno pracowników jak i pracodawców współfinansujących składki emerytalne. Opodatkowaniu podlegają natomiast wszystkie wypłaty z planów emerytalnych [Registered Pension Plan - RPP - Investopedia].

4 Szerzej na ten temat zob. m.in.: Bednarczyk i Szwedo [2016].

5 W 2015 roku przeciętne miesięczne świadczenie emerytalne z CCP w wieku 65 lat wynosiło 640,23 CAN, a maksymalne miesięczna emerytura 1 065,00 CAN. Maksymalne świadczenie możliwe do przyznania w 2016 wynosiło 1 092,50 CAN [Retirement Income...]. 
W 2014 roku w ramach pracowniczych programów emerytalnych oszczędzało ponad 6,2 miliona Kanadyjczyków [Registed Pension Plans...]. Wskaźnik partycypacji wśród osób w wieku 15-64 lat wynosił $26 \%$. Pracownicze programy emerytalne funkcjonują na zasadzie zdefiniowanego świadczenia lub zdefiniowanej składki. Mogą też zawierać rozwiązania mieszane (hybrydowe). Zdecydowana większość uczestników (ponad 70 proc.) wybrała programy o zdefiniowanym świadczeniu. Plany o zdefiniowanej składce cieszą się zdecydowanie mniejszym zainteresowaniem. Ich udział z roku na rok spada. Świadczy to o tym, że Kanadyjczycy preferują rozwiązania, które gwarantują wysokość przyszłych świadczeń i unikają brania na siebie ryzyka inwestycyjnego. Podobny trend charakterystyczny jest również dla rynku zakładowych programów emerytalnych w Stanach Zjednoczonych i Wielkiej Brytanii [Pieńkowska-Kamieniecka 2010: 153].

Indywidualne plany emerytalne, które w Kanadzie przyjęły nazwę Registered Retirement Savings Plans funkcjonują począwszy od 1957 roku. Dedykowane są zarówno pracownikom jak i osobom prowadzącym własną działalność gospodarczą, które nie ukończyły 71 roku życia. Są one oferowane przez banki, kasy oszczędnościowe, fundusze inwestycyjne oraz ubezpieczycieli. Indywidualne plany emerytalny występują wyłącznie $\mathrm{w}$ formule zdefiniowanej składki. W celu pobudzenia indywidualnych oszczędności emerytalnych podlegają one także ulgom podatkowym w systemie EET. Maksymalny limit składkowy (tzw. contribution room) jest określany urzędowo dla poszczególnych prowincji. Począwszy od 2010 r. jest indeksowany do rocznego wzrostu przeciętnego wynagrodzenia. W 2015 r. limit ten ustalono na 24930 CAN lub 18 proc. rocznych dochodów z poprzedniego roku [How contributions...].

Najnowszym rozwiązaniem w ramach trzeciego filara emerytalnego, wprowadzonym w 2009 roku - są wolne od podatku konta oszczędnościowe (Tax Free Savings Account) dedykowane wszystkim dorosłym obywatelom Kanady (powyżej 18 roku). Wpłaty na te konta oszczędnościowe są limitowane. Według zasad obowiązujących od 2013 roku maksymalna roczna kwota wynosi 5500 CAN. Przewidziano tutaj ulgi podatkowe $\mathrm{w}$ systemie TEE (tax-exempt-exempt). Warto podkreślić, że wypłaty $\mathrm{z}$ konta mogą być dokonywane w dowolnym czasie bez utraty ulgi w podatku od zysków kapitałowych. Kanadyjczycy wykazują spore zainteresowanie tą formą oszczędzania. W latach 2009-2013 nastąpił wzrost oszczędzających o ponad 50 proc. [Registered Pension Plans ...: 2015].

Reasumując należy stwierdzić, że w 2013 r. wskaźnik partycypacji $\mathrm{w}$ indywidualnych programach emerytalnych wyniósł 25 proc. [OECD 2015b: 187]. Biorąc pod uwagę wskaźniki partycypacji zarówno w pra- 
cowniczych jak i indywidualnych programach emerytalnych należy zauważyć, że nadal 3/4/4 pracujących Kanadyjczyków nie uczestniczy w dobrowolny filarze emerytalnym, co uznać należy jako zjawisko niepokojące. Przyczyn tego stanu rzeczy jest z pewnością wiele. Wydaje się jednak, że dla osób, które „zamrażają” swoje środki w dobrowolnych oszczędnościach emerytalnych, korzyści w postaci odliczenia od podatku dochodowego oraz brak podatku od inwestycji kapitałowych, postrzegane są jako zbyt małe wobec kosztu jakim jest brak możliwości swobodnego dysponowania tymi środkami.

\section{Mobilizowanie dobrowolnych oszczędności emerytalnych w Nowej Zelandii}

W poszukiwaniu sposobów na zwiększanie poziomu partycypacji zatrudnionych $\mathrm{w}$ dobrowolnych formach oszczędzania na emeryturę, pojawiły się $\mathrm{w}$ ostatnich latach nowatorskie rozwiązania $\mathrm{w}$ postaci automatycznego zapisu (automatic enrolment). Takie rozwiązania wprowadzono m.in. w: USA (1998), Nowej Zelandii (2007), Włoszech (2007), Kanadzie (2012 na poziomie federalnym) oraz Wielkiej Brytanii (2012) [OECD2014: 151]. Jednak tylko w Nowej Zelandii udało się osiągnąć imponujący i najwyższy na świecie wskaźnik partycypacji w programach indywidualnych (por. tabela 1).

\begin{tabular}{|l|c|c|}
\hline \multicolumn{1}{|c|}{ Kraj } & Programy pracownicze & Programy indywidualne \\
\hline Kanada & 26 & 25 \\
\hline Nowa Zelandia & 7 & 73 \\
\hline Wielka Brytania & 30 & 11 \\
\hline USA & 42 & 22 \\
\hline Włochy & 7 & 9 \\
\hline
\end{tabular}

* odsetek populacji pracujących w wieku 15-64 lat, będących uczestnikami dobrowolnych programów emerytalnych

Tabela 1. Wskaźnik partycypacji* w krajach, które wprowadziły automatyczny zapis do dobrowolnych programów emerytalnych w \% (dane za 2013 rok)

Źródło: opracowanie własne na podstawie: [OECD 2015b: 187].

Nowozelandzki system emerytalny, podobnie jak kanadyjski składa się z trzech filarów, nie są one jednak tożsame. Pierwszy filar emerytalny w systemie nowozelandzkim, podobnie jak w kanadyjskim - to emery- 
tura obywatelska oparta na zasadzie zaopatrzeniowej. Stopa zastąpienia netto jest tutaj trochę wyższa i wynosi $40 \%$. W Nowej Zelandii, w przeciwieństwie do Kanady, nie występuje obligatoryjny filar ubezpieczeniowy. Mianem drugiego filaru określa się tutaj nowowprowadzony system dodatkowego oszczędzania na emeryturę pod nazwą KiwiSaver. Trzeci filar, podobnie jak w innych krajach, ma charakter dobrowolny i kapitałowy. Stanowią go indywidualne programy emerytalne zakładane do 2007 roku, które jednak nie zdobyły większej popularności.

Program oszczędnościowy KiwiSaver polega na połączeniu automatycznego zapisu z silnymi bodźcami do pozostania w systemie w postaci dopłat ze strony rządu i pracodawców. Automatyczny zapis nie dotyczy wszystkich potencjalnych uczestników, a jedynie pracowników w wieku 18-64 lat wchodzących na rynek pracy lub zmieniających pracę zawodową. W drugim roku funkcjonowania KiwiSaver zapisano automatycznie wszystkich pracowników sektora publicznego i sektora edukacji [www1]. Do systemu oszczędnościowego mogą przystąpić także osoby prowadzące własną działalność gospodarczą, osoby nie pracujące w wieku do 65 lat oraz uczniowie lub studenci będący obywatelami Nowej Zelandii. Zasada automatycznego zapisu uwzględnia opcję rezygnacji (opt-out). Oznacza to, że pracownik automatycznie zapisany do systemu może się z niego wypisać w określonym czasie (od dwóch do ośmiu tygodni od momentu zapisu $)^{6}$. Później pracownik nie ma już możliwości wypisania się z systemu, może jedynie zmienić dostawcę programu lub strategie inwestycyjną. Z systemu nie może również zrezygnować osoba, która została zapisana do systemu w wyniku własnej decyzji.

Po dziewięciu latach funkcjonowania systemu KiwiSaver można stwierdzić, że odniósł on bezprecedensowy sukces. Według danych z 2015 roku w programie oszczędnościowym uczestniczyło ponad 80 proc. populacji w wieku produkcyjnym. Prawie połowa z nich zapisała się bezpośrednio u dostawcy programu (scheme providers). Na zasadzie automatycznego zapisu włączone do programu tylko niecałe 40 proc. uczestników.

Głównym narzędziem (motywatorem) mobilizowania dodatkowych oszczędności emerytalnych w systemie KiwiSaver okazały się zachęty finansowe. Jeżeli pracownik zobowiąże się oszczędzać w ramach systemu KiwiSaver, pracodawca jest zobligowany dopłacać mu kwotę stanowiącą równowartość 3 proc. jego zarobków brutto. W 2015 roku wartość no-

6 Jak pokazują dane, najwięcej rezygnacji odnotowani w pierwszych trzech latach funkcjonowania systemu KiwiSaver - ponad 50 proc. automatycznie zapisanych pracowników. W kolejnych latach skala rezygnacji była coraz mniejsza. W roku 2015 odsetek wypisanych wynosił tylko 24 proc. [www1]. 
wych wpłat do systemu, wniesionych razem przez pracowników i pracodawców wyniosła blisko 4 mld NZD, co stanowiło 1,6 proc. PKB (por. tabela 2).

System KiwiSaver nie odniósłby sukcesu bez silnego zaangażowania rządu. Pierwszą formą wsparcia finansowego była jednorazowa dopłata startowa (kick-start payment) dla na nowo otwartego konto oszczędnościowego ${ }^{7}$. Drugi rodzaj to dopłata roczna regularna do składek pracownika (member tax credit). Początkowo wynosiła ona 1042,86 NZD (według zasady 1 dolar od rządu za każdy 1 dolar wpłacony), a od 2011 roku dopłata regularna została zmniejszona o połowę (50 centów od rządu za każdy 1 dolar wpłacony na konto pracownika). W 2015 r. dopłaty rządowe wyniosły ponad $800 \mathrm{mln}$ NZD, co stanowiło 17 proc. wszystkich prywatnych środków przekazanych do KiwiSaver w tym roku.

\begin{tabular}{|l|r|r|r|r|r|r|r|r|}
\hline \multicolumn{1}{|c|}{ Wyszczególnienie } & \multicolumn{7}{|c|}{ Lata } \\
\cline { 2 - 9 } & 2008 & 2009 & \multicolumn{1}{|c|}{2010} & \multicolumn{1}{|c|}{2011} & \multicolumn{1}{c|}{2012} & \multicolumn{1}{c|}{2013} & 2014 & 2015 \\
\hline $\begin{array}{l}\text { Suma składek pracowni- } \\
\text { ków i pracodawców } \\
\text { (w mln NZD) }\end{array}$ & 465,6 & 1277,4 & 1685,6 & 1911,5 & 2203,8 & 2393,1 & 3359,0 & 3997,9 \\
\hline $\begin{array}{l}\text { Suma składek pracowni- } \\
\text { ków i pracodawców jako } \\
\text { proc. PKB }\end{array}$ & & & 0,8 & 0,9 & 1,0 & 1,1 & 1,4 & 1,6 \\
\hline $\begin{array}{l}\text { Dotacje rządowe } \\
\text { (w mln NZD) }\end{array}$ & 571,8 & 838,9 & 962,2 & 999,3 & 1044,3 & 676,8 & 737,2 & 803,6 \\
\hline $\begin{array}{l}\text { Udział dotacji rządowych } \\
\text { w całości oszczędności } \\
\text { w KiwiSaver(w proc.) }\end{array}$ & 55 & 40 & 36 & 34 & 32 & 18 & 18 & 17 \\
\hline $\begin{array}{l}\text { Wartość skumulowana } \\
\text { aktywów w KiwiSaver } \\
\text { (w mld NZD) }\end{array}$ & & & 5,85 & 9,19 & 12,74 & 16,56 & 21,40 & 28,47 \\
\hline $\begin{array}{l}\text { Dynamika skumulowa- } \\
\text { nych aktywów (w proc.) }\end{array}$ & & & 100 & 157 & 139 & 130 & 129 & 133 \\
\hline $\begin{array}{l}\text { Udział skumulowanych } \\
\text { aktywów w PKB } \\
\text { (w proc.) }\end{array}$ & & & 2,9 & 4,3 & 5,9 & 7,3 & 9,0 & 11,6 \\
\hline Wartość PKB (w mld) & & & 201,8 & 213,6 & 215,8 & 226,9 & 237,8 & 245,4 \\
\hline
\end{tabular}

Tabela 2. Roczne wpłaty do programów emerytalnych w ramach KiwiSaver w latach 2008-2015 Źródło: opracowanie własne na podstawie danych ze strony [www1] oraz Financial Markets Authority [2016: 10].

Wartość skumulowana aktywów (wszystkich składek i dopłat rządowych powiększona o zyski $\mathrm{z}$ inwestycji $\mathrm{w}$ ramach KiwiSaver) rośnie w tempie ok. 30 proc. rocznie. W 2015 r. system KiwiSaver zgromadził

7 Dopłata startowa wynosiła 1000 NZD, ale od 21.05. 2015 rząd wycofał się z niej. 
aktywa o wartości blisko 28,5 mld NZD, co stanowiło 11,6 proc. PKB. Warto podkreslić, że skumulowana wartość aktywów rośnie pomimo, że udział dotacji rządowych w całości oszczędności w KiwiSaver maleje z 55 proc. w roku 2008 do 17 proc w roku 2015. Zjawisko to należy ocenić pozytywnie.

O sukcesie systemu KiwiSaver świadczy również struktura wiekowa i dochodowa oszczędzających. Należy zauważyć, że największą grupę oszczędzających tworzą osoby młode do 35 roku życia. W 2015 roku co drugi uczestnik KiwiSaver pochodził z tej grupy wiekowej, a co czwarty z nich nie przekroczył 24 roku życia [www2].

System oszczędzania KiwiSaver zaktywizował także grupę Nowozelandczyków o niskich i średnich dochodach. Osoby o dochodach z przedziału od 1000 NZD do 20000 NZD stanowiły w 2015 r. 30 proc. uczestników. Oszczędzający z przedziału dochodowego od 20000 NZD do 40000 NZD stanowily kolejne 25 proc. Warto jednak odnotować, że z roku na rok delikatnie spada udział uczestników najmniej zarabiających, natomiast zwiększa się odsetek oszczędzających z zarobkami rocznymi z przedziału od 40000 NZD do 60000 NZD [www2].

\section{Podsumowanie}

Zarówno społeczeństwo kanadyjskie jak i nowozelandzkie jest stosunkowo zamożne i cechujące się relatywnie wysoką świadomością ubezpieczeniową i emerytalną, dlatego w dużym stopniu wykorzystuje rozwiązania rynkowe. Filar bazowy w postaci emerytury obywatelskiej w obydwu krajach gwarantuje relatywnie niską stopę zastąpienia, a zatem Kanadyjczycy i Nowozelandczycy, chcąc zachować dotychczasowy standard życia na emeryturze, są w naturalny sposób zmotywowani do dodatkowego indywidualnego oszczędzania. Jednak na ostateczne efekty mobilizowania dodatkowych oszczędności w ramach programów emerytalnych duży wpływ ma państwo. Prawidłowo skonstruowany system zachęt finansowych stanowi skuteczny bodziec skłaniający do indywidualnego oszczędzania.

Krajem odnoszącym największe sukcesy w angażowaniu społeczeństwa w dobrowolne programy emerytalne i mobilizowaniu dodatkowych oszczędności okazała się Nowa Zelandia. Wprowadzony tam w lipcu 2007 roku nowatorski system oszczędzania pod nazwą KiwiSaver z roku na rok odnotowuje wzrost uczestników i zgromadzonych aktywów. Powodem sukcesu okazała się zasada automatycznego zapisu do dobrowolnych pro- 
gramów emerytalnych, z czasową opcją rezygnacji, połączona z silnymi bodźcami do pozostania $\mathrm{w}$ nim $\mathrm{w}$ postaci dopłat pracodawcy i dotacji budżetowych. Dzięki temu Nowa Zelandia prezentuje jeden z najwyższych na świecie wskaźników partycypacji społeczeństwa w dobrowolnych formach oszczędzania na emeryturę.

System oszczędzania KiwiSaver jest szczególnie dobrze odbierany zwłaszcza przez ludzi młodych. Na tej podstawie można uznać, że dopłaty do dobrowolnych składek oszczędnościowych dają mocniejszy impuls do dodatkowego oszczędzania i tworzenia nowej puli środków niż tradycyjne zwolnienia podatkowe, stosowane np. w Kanadzie. Ich zaletą jest również to, że przynoszą wymierne korzyści także dla pracowników mniej zamożnych (gorzej zarabiających), którzy odprowadzają niskie podatki. System dopłat jest formą wsparcia finansowego również dla osób formalnie nie zatrudnionych, które nie płacą żadnych podatków. Może zatem stanowić bodziec do opuszczania „szarej strefy” i ujawniania dochodów.

Wykorzystanie doświadczeń nowozelandzkich w odniesieniu do polskiego systemu emerytalnego wymaga wprowadzenia nowego zestawu rozwiązań, odnoszących się zarówno do filara repartycyjnego, jak i do filara kapitałowego. Rozwiązania te mogą umożliwić stworzenie systemu emerytalnego, który będzie lepiej odpowiadał na wyzwania demograficzne, społeczne i gospodarcze stojące przed gospodarką polską w tym zakresie $^{8}$.

\section{Bibliografia}

Actuarial Report (12th) on the Old Age Security Program, http://www.osfi-bsif.gc.ca/eng/ oca-bac/ar-ra/oas-psv/pages/oas12.aspx (dostęp: 21.01.2017).

Bednarczyk T.H, Szwedo Ł. (2016), Kanadyjski system emerytalny - model do naśladowania?, „Annales Universitatis Mariae Curie-Skłodowska. Sectio H Oeconomia", vol. L, 4, Lublin.

Czechowska I.D. (2013), Oszczędności gospodarstw domowych w Polsce w okresie kryzysu, „Zarządzanie i Finanse”, vol. 11, nr 2, cz. 4.

Esping-Andersen G. (2010), Trzy światy kapitalistycznego państwa dobrobytu, Warszawa. Financial Markets Authority (2016), KiwiSaver - Annual Report, https://fma.govt.nz/as sets/Reports/151005-FMA-KiwiSaver-Report-2015.pdf (dostęp: 21.01.2017).

8 Pewne propozycje tych zmian spotkać można m.in.: [Strategia...: 2016] i w rekomendacjach zamieszczonych w raporcie KNF [Sektor...: 2016]. 
Friedman M. (1957), A Theory of the Consumption Function, National Bureau of Economic Research, Princeton University Press, Princeton.

Fukuyama F. (1997), Zaufanie - kapitał społeczny a droga do dobrobytu, WarszawaWrocław.

How contributions affect your RRSP/PRPP deduction limit, Canada Revenue Agency, http://www.cra-arc.gc.ca/tx/ndvdls/tpcs/rrsp-reer/cntrbtng/cntrbtngeng.html\# whtddctnlmt (dostęp: 21.01.2017).

Kawalec S., Błażuk K., Kurek M. (2015), Jak mobilizować dodatkowe oszczędności emerytalne?, Capital Strategy, Warszawa.

Keynes J.M. (2003), Ogólna teoria zatrudnienia, procentu i pieniq̨dza, PWN, Warszawa.

Kłos B. (2012), Kanadyjski system emerytalny „„Analizy BAS”, nr 16/83.

Modigliani F., Brumberg R. (1954), Utility Analysis and the Consumption Function: An Interpretation of the Cross-Section Data, [w:] Post-Keynesion Economics, ed. K. Kurihara, Rutgers University Press, New Brunswick.

OECD (2014), OECD Pensions Outlook, http://www.egm.org.tr/makaleler/OECD\%20 Pension\%20Outlook,\%202014.pdf (dostęp: 21.01.2017).

OECD (2015a), Pensions Markets in Focus, http://www.oecd.org/daf/fin/privatepen sions/Pension-Markets-in-Focus-2015.pdf (dostęp: 21.01.2017).

OECD (2015b), Pension at a Glance 2015: OECD and G20 Indicators, http://www.oecdili brary.org/docserver/download/8115201e.pdf?expires=1470771269\&id=id\&accnam e=guest\&checksum=E8261DBB20CAEF03F72F1176D91E5076 (dostęp: 21.01.2017).

Old Age Security Benefits and Canada Pension Plan, Service Canada, http://www.seniors council.net/uploads/files/Federal\%20Programs.pdf (dostęp: 21.01.2017).

Pieńkowska-Kamieniecka S. (2010), System emerytalny w Kanadzie, ,'Wiadomości Ubezpieczeniowe", nr 4.

Pieńkowska-Kamieniecka S., Ostrowska-Dankiewicz A. (2013), Dopłaty do dobrowolnych oszczędności emerytalnych - ocena skuteczności rozwiq̨zań na przykładzie Niemiec i Nowej Zelandii, „Wiadomości Ubezpieczeniowe”, nr 3.

Urząd Komisji Nadzoru Finansowego (2014), Indywidualne konta emerytalne oraz indywidualne konta zabezpieczenia emerytalnego w 2013 roku, Warszawa, https://www.knf. gov.pl/Images/Oprac_IKE_IKZE_12_2013_tcm75-37673.pdf (dostęp: 21.01.2017).

Registered Pension Plan - RPP - Investopedia, http://www.investopedia.com/terms/r/ rpp.asp. (dostęp: 21.01.2017).

Registered Pension Plans (RPP) and Other Types of Savings Plans - Coverage in Canada (2015), http://www.osfi-bsif.gc.ca/Eng/Docs/fs_rpp_2015.pdf (dostęp: 21.01.2017).

Retirement Income: Public and Private Pensions, Old Age Security, http://www.fcac-acfc. gc.ca/Eng/resources/educationalPrograms/ft-of/Pages/retirement-pensions-2-4. aspx (dostęp: 21.01.2017).

Samoń D. (2012), Kiwi na emeryturze poleci wyżej niż orzełek ,,'Analiza FOR”, nr 27, http://static. presspublica.pl/red/rp/doc/mojaemerytura/Analiza_27_2012_Kiwi_na_emeryturze_ poleci_wyzej_niz_orzelek.pdf (dostęp: 21.01.2017). 
Sektor funduszy emerytalnych w Polsce - ewolucja, kształt, perspektywy, UKNF, Warszawa 2016, https://www.knf.gov.pl/Images/Sektor_funduszy_emerytalnych_w_Polsce_2016_ tcm75-47307.pdf (dostęp: 21.01.2017).

Strategia Odpowiedzialnego Rozwoju - Program Budowy Kapitału, Ministerstwo Rozwoju, Warszawa 2016, https://www.mr.gov.pl/media/22008/ProgramBudowyKap italu_prezentacja.pdf (dostęp: 21.01.2017).

Swacha-Lech M. (2013), Motywy oszczędzania w świetle badań sondażowych zrealizowanych we współpracy z Interaktywnym Instytutem Badań Rynkowych w okresie od 1 marca 2013 roku ,"Zarządzanie i Finanse”, vol. 11, nr 2, cz. 4.

Urząd Komisji Nadzoru Finansowego (2014), Pracownicze programy emerytalne w 2013 roku, Warszawa, https://www.knf.gov.pl/Images/RAPORT_PPE_w_2013_ tcm75-38451.pdf (dostęp: 21.01.2017).

[www1] http://www.kiwisaver.govt.nz/statistics/annual/ (dostęp: 21.01.2017).

[www2] http://www.kiwisaver.govt.nz/statistics/annual/joining (dostęp: 21.01.2017).

\section{STYMULOWANIE PRYWATNYCH OSZCZĘDNOŚCI EMERYTALNYCH NA PRZYKŁADZIE KANADY I NOWEJ ZELANDII}

Mobilizowanie dodatkowych oszczędności emerytalnych jest ważne, zarówno z powodu zachodzących zmian demograficznych oraz przewidywanego spadku stóp zastąpienia jak i potrzeb inwestycyjnych gospodarek narodowych. Dlatego rządy krajów wysoko rozwiniętych stosują różne formy zachęt dla dobrowolnego oszczędzania na emeryturę. Artykuł poświęcono analizie i ocenie rozwiązań systemowych dotyczących stymulowania dodatkowych oszczędności emerytalnych w Kanadzie i w Nowej Zelandii. W toku przeprowadzonej analizy dowiedziono, że znacznie bardziej efektywne okazuje się połączenie zasady automatycznego zapisu z dotacjami rządu i dopłatami pracodawców, które są stosowane w nowozelandzkim systemie KiviSaver niż tradycyjne zwolnienia podatkowe stosowane w Kanadzie. Struktura opracowania jest następująca. W pierwszej części przedstawiono rozważania na temat oszczędności emerytalnych i instrumentów ich wspierania. Następnie przedstawiono wybrane zagadnienia dotyczące mobilizowania dodatkowych oszczędności emerytalnych w Kanadzie oraz założenia nowatorskiego systemu gromadzenia oszczędności emerytalnych w ramach KiwiSaver. W zakończeniu znalazły się syntetyczne wnioski.

Słowa kluczowe: oszczędności emerytalne, ulgi podatkowe, dopłaty do składek, zasada automatycznego zapisu. 


\section{ENCOURAGING TO ADDITIONAL RETIREMENT SAVINGS ON THE EXAMPLE OF CANADA AND NEW ZEALAND}

Collection of additional retirement savings is important, both because of demographic changes and the expected decline in replacement rates, as well as due to the investment needs of national economies. Therefore, the governments of developed countries apply incentives for voluntary retirement saving scheme. The paper is devoted to the analysis and evaluation of systemic solutions to stimulate the additional retirement savings in Canada and New Zealand. Within the analysis, it was proved that a combination of the automatic-enrolment from government grants and subsidies of employers, which are used in the New Zealand system KiviSaver turns out to be much more efficient than traditional tax exemptions applied in Canada. The structure of the study is as follows: the first part presented considerations on retirement savings and the instruments to support them, then there were presented selected issues concerning mobilizing additional retirement savings in Canada and the establishment of an innovative system of pension savings within KiwiSaver. The final section of the paper contained synthetic conclusions.

Keywords: retirement savings, tax exemptions, matching contributions, principle of automatic-enrolment. 